\title{
Physicochemical properties of protein-modified silver nanoparticles in seawater
}

Hangyue Zhong

\begin{abstract}
This study investigated the physicochemical properties of silver nanoparticles stabilized with casein protein in seawater. UV-vis spectrometry, dynamic light scattering (DLS), and transmission electron microscopy (TEM) were applied to measure the stability of silver nanoparticles in seawater samples. The obtained results show an increased aggregation tendency of silver nanoparticles in seawater, which could be attributed its relatively high cation concentration that could neutralize the negatively charges adsorbed on the surface of silver nanoparticles and reduce the electrostatic repulsion forces between nanoparticles. Similarly, due to the surface charge screening process, the zeta potential of silver nanoparticles in seawater decreased. This observation further supported the aggregation behavior of silver nanoparticles. This study also investigated the dissolution of silver nanoparticles in seawater. Result shows that the silver nanoparticle dissolution in DI water is lower than in seawater, which is attributed to the high $\mathrm{Cl}^{-}$concentration present in seawater. $\mathrm{As} \mathrm{Cl}^{-}$can react with silver and form soluble AgCl complex, dissolution of silver nanoparticles was enhanced. Finally, this study demonstrated that silver nanoparticles are destabilized in seawater condition. These results may be helpful in understanding the environmental risk of discharged silver nanoparticles in seawater conditions.
\end{abstract}

Keywords: Silver nanoparticles; Casein protein; Seawater; Physicochemical properties

\section{Background}

Silver nanoparticles (SNPs) are widely applied in industries and households due to their antimicrobial properties [1-5]. According to the statistics, consumer products containing SNPs accounted for more than $23 \%$ of the total 1,317 nanotechnology-based consumer products available on the market in 2011 [6].

SNPs can be synthesized by physical or chemical method. Sharma et al. introduced the Tollens' method which involves the reduction of $\mathrm{Ag}\left(\mathrm{NH}_{3}\right)_{2}$ in aqueous Tollens' reagent by an aldehyde such as saccharides [7-11]. During the synthesis process, capping agents are usually used to create a stable SNPs suspension [7,11,12].

Among all the capping agents, casein protein is frequently used due to its good stabilizing effect and low toxicity [6,13-15]. Recent studies show that water chemistry can influence the physicochemical properties of SNPs. For instance, Gao et al. suggested that water conditions

Correspondence: jiangangwei1980@163.com

Department of Environmental Engineering, University of Henan, Kaifeng, Henan 475004, China of high ionic strength form large aggregates [16]. It is also reported that the size of SNPs aggregates can influence their toxicity. For example, larger SNPs aggregates exhibit lower toxicity on bacteria and human cells compared to smaller SNPs aggregates [16-18]. Liu and coauthors show that the dissolution of SNPs depends on environmental parameters, such as $\mathrm{pH}$, dissolved oxygen, temperature, and ionic strength $[19,20]$. However, few research studies have compared the stability of SNPs in terms of physicochemical properties including particles size, zeta potential, and dissolution in natural water conditions [21-25].

In this work, SNPs capped with casein protein were purchased from Xianfeng Nanotechnology, Inc. Nanjing, Jiangsu, China. Casein protein-stabilized SNPs were selected because casein is an environmentally friendly polymeric coating and frequently used by other researchers for SNPs' characterization and antimicrobial activity tests $[6,13]$. To investigate the physicochemical properties of SNPs, we chose deionized (DI) water and seawater conditions to compare our findings. Particle sizes of SNPs in DI

\section{Springer}

C 2013 Zhong; licensee Springer. This is an open access article distributed under the terms of the Creative Commons Attribution License (http://creativecommons.org/licenses/by/2.0), which permits unrestricted use, distribution, and reproduction in any medium, provided the original work is properly cited. 
water and seawater conditions were measured using a dynamic light scattering (DLS) technique. Zeta potentials of SNPs were recorded to study their stability. Dissolution kinetics of SNPs was studied using ultrafiltration membranes in combination with inductively coupled plasma mass spectrometry (ICP-MS). The result obtained in this study may serve as a reference for the risk assessment of the release of SNPs into natural water bodies since the availability and mobility of SNPs is highly dependent on the sizes of their aggregates.

\section{Methods}

\section{Electrolyte solutions and natural water sample preparation}

Seawater was collected from the Bohai sea near the coast of Weihai city. The water samples collected were first filtered $(0.45 \mu \mathrm{m})$ and then autoclaved to remove microorganisms in the waters. The major ionic component was analyzed using ion chromatography (IC) techniques (DX-120, Dionex Corp., Sunnyvale, CA, USA). Concentrations of natural organic matter in these natural water samples were measured as total organic carbon (TOC) using a TOC analyzer (Apollo 9000, Tekmar Dohrman series, Teledyne Tekmar, Mason, OH, USA). Major compositions of seawater were listed in Table 1.

\section{Characterization and physicochemical properties of silver nanoparticles}

Casein-stabilized SNPs were purchased from Xianfeng Nanotechnology, Inc. Casein was used because it is an environmentally friendly stabilizer and was widely used in previous research. The SNPs were dissolved in DI water. UV-vis absorption spectra of SNPs in DI water and seawater were recorded using a spectrophotometer (Thermo Unicam; Thermo Fisher Scientific, NH, USA). Concentration of SNPs was measured by ICP-MS (X series, Thermo Elemental, Thermo Fisher Scientific, NH, USA). Cryotransmission electron microscope (cryo-TEM) was used to observe the morphology of SNPs. Surface charge and average hydrodynamic size of SNPs in different water conditions were determined in triplicate by DLS using a Zetasizer (Nano ZS, ZEN 3600, Malvern Instruments Ltd, Worcestershire, UK) at $25^{\circ} \mathrm{C}$. The dissolution of SNPs was determined by filtrating the SNPs in DI/seawater using a 3,000 molecular cut-off membrane manufactured by Millipore (Millipore Corporation, Billerica, MA, USA) under centrifugation at the speed of $4,000 \mathrm{rpm}$. The

Table 1 Chemical composition of collected seawater

\begin{tabular}{lllllll}
\hline $\begin{array}{llllll}\text { Water } \\
\text { sample }\end{array}$ & $\begin{array}{l}\text { DO } \\
(\mathbf{m g} / \mathbf{L})\end{array}$ & $\begin{array}{l}\text { TOC } \\
(\mathbf{m g} / \mathbf{L})\end{array}$ & \multicolumn{5}{l}{ Major ions $\mathbf{( m g / L )}$} \\
\cline { 4 - 7 } & & $\mathbf{N a}^{+}$ & $\mathbf{M g}^{2+}$ & $\mathbf{C a}^{2+}$ & $\mathbf{C l}^{-}$ \\
\hline Seawater & 8.6 & 2.0 & 12,329 & 1,480 & 450 & 22,300 \\
\hline
\end{tabular}

filtration process enables the separation of SNPs with dissolved silver ions. The filtrates were amended with nitric acid for sample preservation and were measured by ICP-MS.

\section{Results and discussion}

\section{Characterization of silver nanoparticles}

The SNP suspension is used for TEM and UV-vis spectra which were recorded under identical conditions using a JEOL 2100 TEM (JEOL Ltd., Tokyo, Japan) and a Thermo Unicam UV-vis spectrophotometer at the concentration of $10 \mathrm{mg} / \mathrm{L}$. As shown in Figure 1, SNPs exhibited near-spherical shape. The surface plasmon resonance band of SNPs was located at $408 \mathrm{~nm}$. The

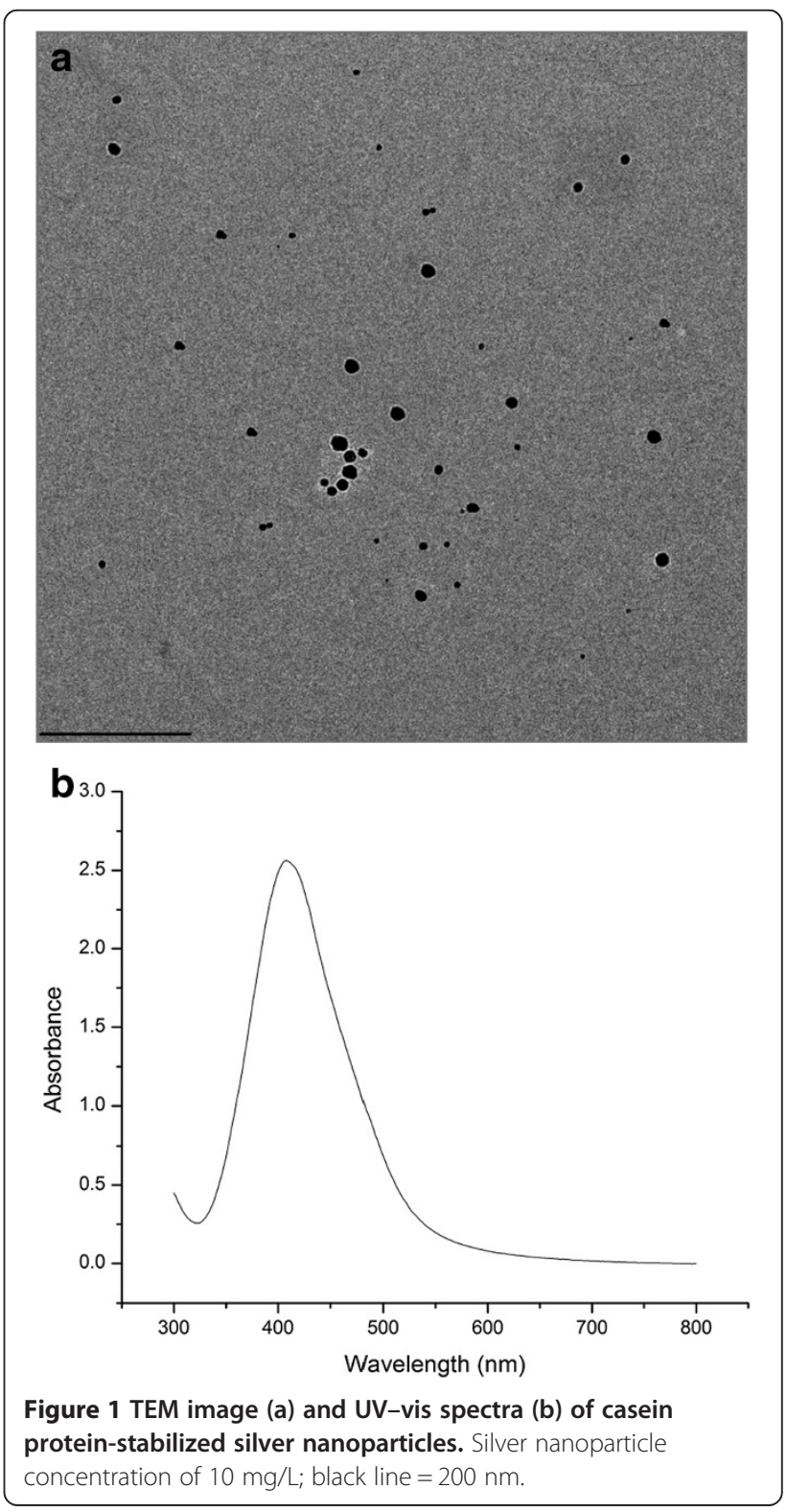


observation is consistent with previous published literatures [11].

\section{Stability of silver nanoparticles}

Figure 2 shows the stability of SNPs in DI water Figure 2a and seawater Figure $2 b$ measured by UV-vis spectrometer. As UV-vis surface plasmon resonance band did show significant changes, Figure $2 \mathrm{a}$ indicates good stability of SNPs in DI water. However, in seawater, surface plasmon resonance band decreases over time, indicating decreasing stability of SNPs. This is because the SNPs form large-size agglomerate in seawater. The sedimentation of the agglomerates leads to a decreasing surface plasmon resonance band [26].

The particle size of SNP aggregates was further measured by DLS. Figure 3 presents the size and shape of SNPs when they were suspended in DI water and different

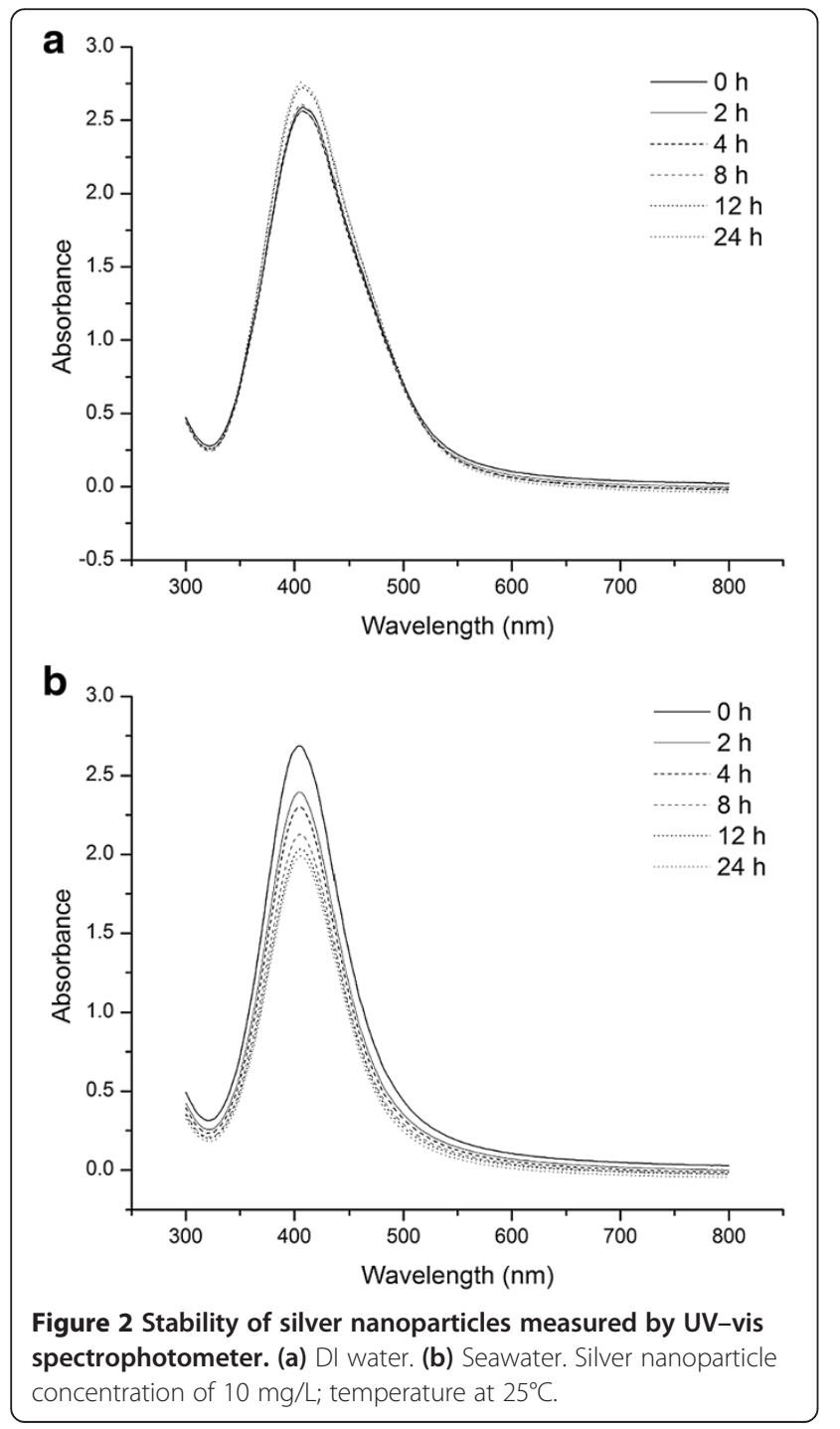

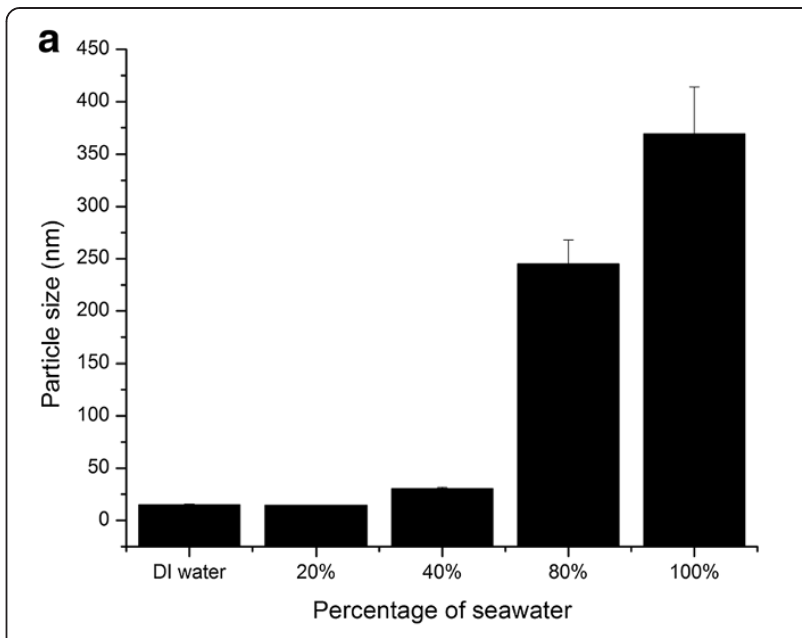

b

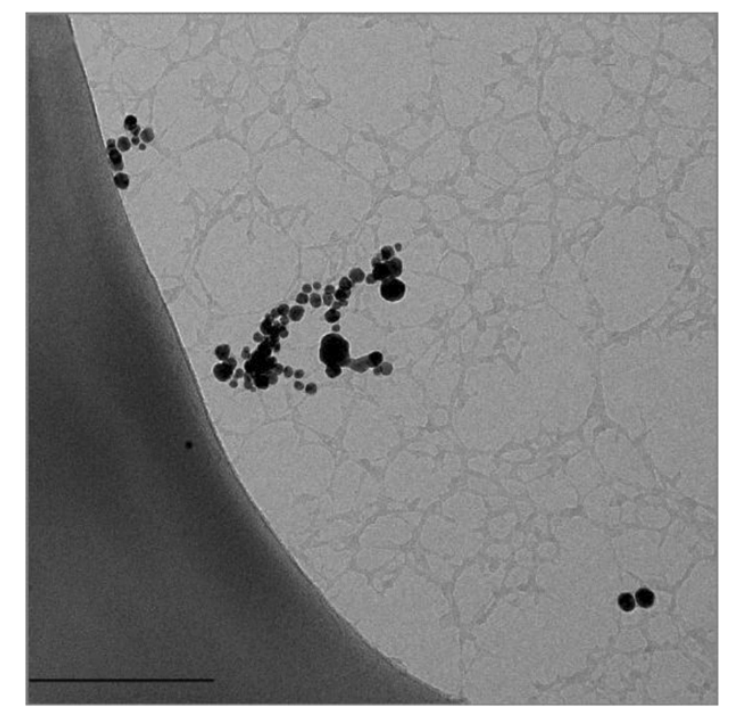

Figure 3 Particle size of silver nanoparticles in various percentages of seawater (a) and TEM of image of the silver nanoparticle aggregates (b). Silver nanoparticle concentration of $10 \mathrm{mg} / \mathrm{L}$; temperature at $25^{\circ} \mathrm{C}$; reaction time at $24 \mathrm{~h}$. Black line $=200 \mathrm{~nm}$.

percentages of seawater. It can be seen that the average size of SNPs was stable in DI water but increases with increasing percentages of seawater. This is because cations present in seawater can neutralize the surface charge of negatively charged SNPs. Thus, increase in the cation concentration results in an enhanced surface screening process leading to larger SNP aggregates. This observation agrees with the Schulze-Hardy rule which indicates that the stability of a typical colloidal system is extremely sensitive to the valence of the counter ions. Similarly, Zhang et al. reported that seawater produces larger SNP (stabilized with dextrin, casein, and PVP) aggregates than lake water, ground water, and brackish water and attributed aggregation to the surface neutralization of 
SNPs by the presence of cations, particularly divalent cations [6]. Zhang et al. suggested that different coating stabilizers can also affect the SNP aggregation due to the intrinsic nature of the stabilizers [6,27]. Gao et al. also observed this phenomenon, which showed that SNPs in seawater can form larger aggregates [16]. On the contrary, as ionic species were not present in DI water, SNPs show relatively high stability in DI water condition [28]. The shape and size of the aggregated SNPs shown in Figure $3 \mathrm{~b}$ are similar to that in Figure 1 but clear aggregation was observed.

In addition to the surface neutralization process, natural organic matters present in seawater can mitigate the formation of SNP aggregates [26,29,30]. Greater mitigating effect was observed with increasing addition of natural organic matter in previous publications [31-33]. This mitigating effect of $\mathrm{HA}$ is due to its adsorption on the surface of nanoparticles, which creates steric repulsion forces against aggregation of nanoparticles [32]. However, in our case, the surface charge screening process by cations is so overwhelming that the stabilizing effect of natural organic matters can be ignored.

Zeta potential refers to the stability of the colloidal systems. Its value (negative or positive) indicates the degree of repulsion between adjacent or charged particles in a colloidal system. As Figure 4 shows, both SNPs in DI water and seawater exhibit negative zeta potential attributed to the adsorption of various anions onto the SNP surface. The data also suggests that the zeta potential of SNP solutions becomes less negative as the percentage of seawater increases due to the screening of the negative charges on the surface of SNPs by the cations [34-36].

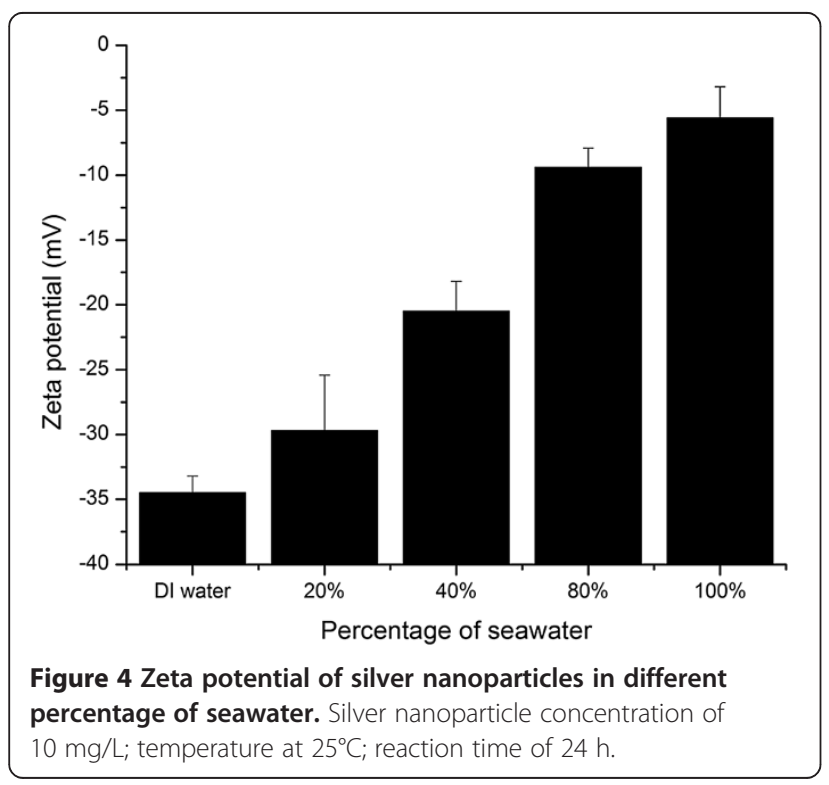

\section{Dissolution of silver nanoparticles in seawater}

In the water environment, surface of SNPs can be oxidized by dissolved oxygen in water and silver ions can be released:

$$
\begin{aligned}
& \mathrm{Ag}+\frac{1}{4} \mathrm{O}_{2}=\frac{1}{2} \mathrm{Ag}_{2} \mathrm{O}_{(\mathrm{S})} \\
& \frac{1}{2} \mathrm{Ag}_{2} \mathrm{O}_{(\mathrm{S})}+\frac{1}{2} \mathrm{H}_{2} \mathrm{O}=\mathrm{Ag}^{+}+\mathrm{OH}^{-}
\end{aligned}
$$

In the presence of seawater, the $\mathrm{Cl}^{-}$can react with released silver ions by forming insoluble $\mathrm{AgCl}$ precipitate [28]:

$$
\mathrm{Ag}^{+}+\mathrm{Cl}^{-}=\mathrm{AgCl}_{(\mathrm{s})}
$$

However, when large amount of $\mathrm{Cl}^{-}$is present, it can react with the $\mathrm{AgCl}$ precipitate and form the soluble forms of $\mathrm{AgCl}$ complexes.

The abovementioned reactions can explain the soluble silver measurement as shown in Figure 5. In low percentage of seawater, the $\mathrm{Cl}^{-}$reacts with dissolved silver producing $\mathrm{AgCl}$ precipitate, which results in decreased soluble silver detection. When the percentage of seawater increases, the excessive $\mathrm{Cl}^{-}$can form soluble $\mathrm{AgCl}$ complexes and therefore increase the soluble silver concentration. This observation is consistent with published data [20,37].

\section{Conclusions}

This study elucidated the physicochemical properties of SNPs in seawater conditions. The obtained results indicated that SNPs in seawater is less stable than in DI water. In brief, particle size and absolute values of zeta potentials of SNPs increase with increasing percentage of seawater due to the surface charge neutralization process by the cations present. However, seawater can

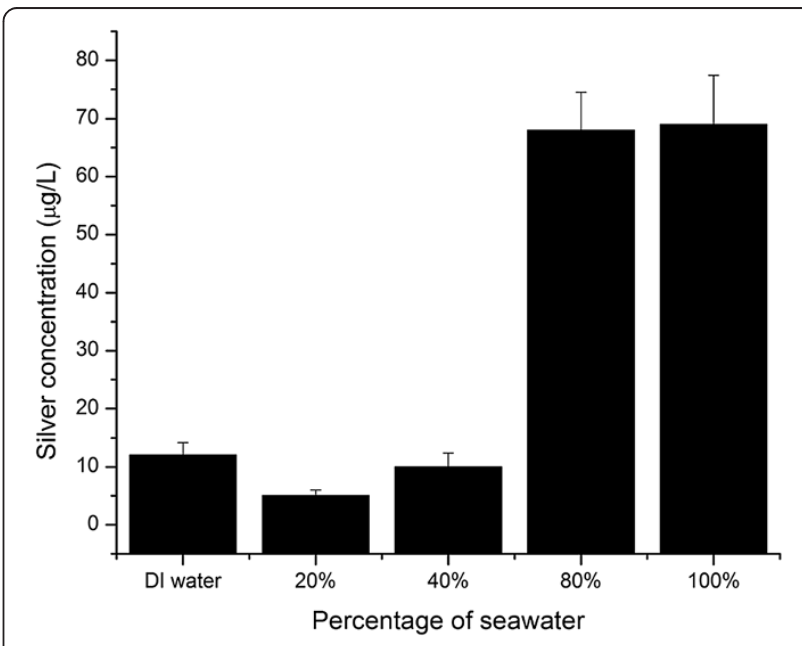

Figure $\mathbf{5}$ Dissolution of silver nanoparticles. Silver nanoparticle concentration of $10 \mathrm{mg} / \mathrm{L}$; temperature at $25^{\circ} \mathrm{C}$; reaction time of $24 \mathrm{~h}$. 
enhance dissolution of SNPs by reacting with dissolved silver to form soluble $\mathrm{AgCl}$ complexes. The work has partly revealed the fate of SNPs in seawater conditions. It can be helpful for the risk assessment of nanomaterial release into the natural aquatic environment.

\section{Competing interest}

The author declares no competing interest.

\section{Acknowledgments}

The author would like to acknowledge University of Henan for its generous funding to support this research.

\section{Received: 5 August 2013 Accepted: 22 September 2013}

\section{Published: 10 Oct 2013}

\section{References}

1. Suresh, AK, Pelletier, DA, Doktycz, MJ: Relating nanomaterial properties and microbial toxicity. Nanoscale 5, 463-474 (2013)

2. Tiwari, DK, Behari, J, Sen, P: Application of nanoparticles in waste water treatment. World Appl. Sci. J. 3, 417-433 (2008)

3. Choi, O, Clevenger, TE, Deng, B, Surampalli, RY, Ross Jr, L, Hu, Z: Role of sulfide and ligand strength in controlling nanosilver toxicity. Water Res. 43(7), 1879-1886 (2009)

4. Choi, O, Deng, KK, Kim, NJ, Ross Jr, L, Surampalli, RY, Hu, Z: The inhibitory effects of silver nanoparticles, silver ions, and silver chloride colloids on microbial growth. Water Res. 42(12), 3066-3074 (2008)

5. Chen, S, Zhang, H: Effect of different anionic ligands on toxicity of silver nanoparticles. Asian J Chem 25, 2909-2911 (2013)

6. Zhang, H, Smith, J, Oyanedel-Craver, V: The effect of natural water conditions on the anti-bacterial performance and stability of silver nanoparticles capped with different polymers. Water Res. 46, 691-699 (2012)

7. Sharma, VK, Yngard, RA, Lin, Y: Silver nanoparticles: green synthesis and their antimicrobial activities. Adv. Colloid Interface Sci. 145(1-2), 83-96 (2009)

8. Morones, JR, Elechiguerra, JL, Camacho, A, Holt, K, Kouri, JB, Ramirez, JT, Yacaman, MJ: The bactericidal effect of silver nanoparticles. Nanotechnology 16(10), 2346-2353 (2005)

9. Kittler, S, Greulich, C, Diendorf, J, Koller, M, Epple, M: Toxicity of silver nanoparticles increases during storage because of slow dissolution under release of silver ions. Chem. Mater. 22(16), 4548-4554 (2010)

10. Kvitek, L, Panacek, A, Soukupova, J, Kolar, M, Vecerova, R, Prucek, R, Holecova, M, Zboril, R: Effect of surfactants and polymers on stability and antibacterial activity of silver nanoparticles (NPs). J. Phys. Chem. C 112, 5825-5834 (2008)

11. Panacek, A, Kvitek, L, Prucek, R, Kolar, M, Vecerova, R, Pizurova, N, Sharma, VK, Nevecna, T, Zboril, R: Silver colloid nanoparticles: synthesis, characterization and their antibacterial activity. J. Phys. Chem. C 110, 16248-16253 (2006)

12. Rai, M, Yadav, A, Gade, A: Silver nanoparticles as a new generation of antimicrobials. Biotechnol. Adv. 27(1), 76-83 (2009)

13. Zhang, $\mathrm{H}$, Oyanedel-Craver, V: Evaluation of the disinfectant performance of silver nanoparticles in different water chemistry conditions. J Environ Eng 138, 58-66 (2011)

14. Ren, D, Smith, JA: Proteinate-capped silver nanoparticle transport in water-saturated sand. J Environ Eng , (2012). 121119223630003

15. Liu, Y, Guo, R: The interaction between casein micelles and gold nanoparticles. J. Colloid Interface Sci. 332(1), 265-269 (2009)

16. Gao, J, Youn, S, Hovsepyan, A, Llaneza, V, Wang, Y, Bitton, G, Bonzongo, JJ: Dispersion and toxicity of selected manufactured nanomaterials in natural river water samples: effects of water chemical composition. Environ. Sci. Technol. 43, 3322-3328 (2009)

17. Jin, $X, L i, M$, Wang, J, Marambio-jones, C, Peng, F, Huang, $X$, Damoiseaux, $R$, Hoek, EMV: High-through screening of silver nanoparticle stability and bacterial inactivation in aquatic media: Influence of specific ions. Environ. Sci. Technol. 44, 7321-7328 (2010)

18. Zook, JM, MacCuspie, RI, Locascio, LE, Halter, MD, Elliott, JT: Stable nanoparticle aggregates/agglomerates of different sizes and the effect of their size on hemolytic cytotoxicity. Nanotoxicology 5, 517-530 (2011)

19. Liu, J, Hurt, RH: Ion release kinetics and particle persistence in aqueous nano-silver colloids. Environ. Sci. Technol. 44, 2169-2175 (2010)
20. Liu, J, Sonshine, DA, Shervani, S, Hurt, R: Controlled release of biologically active silver from nanosilver surfaces. ACS Nano 4, 6903-6913 (2010)

21. Cumberland, SA, Lead, JR: Particle size distributions of silver nanoparticles at environmentally relevant conditions. J. Chromatogr. A 1216(52), 9099-9105 (2009). doi:10.1016/j.chroma.2009.07.021

22. Delay, M, Dolt, T, Woellhaf, A, Sembritzki, R, Frimmel, FH: Interactions and stability of silver nanoparticles in the aqueous phase: influence of natural organic matter (NOM) and ionic strength. J Chromatography A 1218(27), 4206-4212 (2011)

23. Elimelech, M, Gregory, J, Jia, X, Williams, R: Particle Deposition and Aggregation: Measurement, Modelling and Simulation. Butterworth-Heinemann, Oxford (1995)

24. Levard, C, Hotze, EM, Lowry, GV, Brown Jr, GE: Environmental transformations of silver nanoparticles: impact on stability and toxicity. Environ. Sci. Technol. 46(13), 6900-6914 (2012)

25. Park, MV, Neigh, AM, Vermeulen, JP, de la Fonteyne, LJ, Verharen, HW Briede, JJ, van Loveren, $H$, de Jong, WH: The effect of particle size on the cytotoxicity, inflammation, developmental toxicity and genotoxicity of silver nanoparticles. Biomaterials 32(36), 9810-9817 (2011)

26. Chinnapongse, SL, MacCuspie, RI, Hackley, VA: Persistence of singly dispersed silver nanoparticles in natural freshwaters, synthetic seawater, and simulated estuarine waters. Sci. Total Environ. 409(12), 2443-2450 (2011)

27. Chen, S, Zhang, H: Aggregation and dissolution kinetics of nanosilver in seawater. Asian J Chem 25, 2886-2888 (2013)

28. Li, X, Lenhart, JJ, Walker, HW: Dissolution-accompanied aggregation kinetics of silver nanoparticles. Langmuir 26(22), 16690-16698 (2010)

29. Fabrega, J, Fawcett, SR, Renshaw, JC, Lead, JR: Silver nanoparticle impact on bacterial growth: effect of pH, concentration, and organic matter. Environ. Sci. Technol. 43, 7285-7290 (2009)

30. Li, X, Lenhart, JJ, Walker, HW: Aggregation kinetics and dissolution of coated silver nanoparticles. Langmuir 28(2), 1095-1104 (2012)

31. Baalousha, M, Nur, Y, Romer, I, Tejamaya, M, Lead, JR: Effect of monovalent and divalent cations, anions and fulvic acid on aggregation of citrate-coated silver nanoparticles. Sci. Total Environ. 454-455, 119-131 (2013)

32. El Badawy, AM, Luxton, TP, Silva, RG, Scheckel, KG, Suidan, MT, Tolaymat, TM: Impact of environmental conditions ( $\mathrm{pH}$, ionic strength, and electrolyte type) on the surface charge and aggregation of silver nanoparticles suspensions. Environ. Sci. Technol. 44, 1260-1266 (2010)

33. Chen, $\mathrm{S}$, Zhang, $\mathrm{H}$ : Aggregation kinetics of nanosilver in different water conditions. Adv. Nat. Sci. Nanosci. Nanotechnol. 3(3), 035006 (2012). doi:10.1088/2043-6262/3/3/035006

34. Thio, BJ, Montes, MO, Mahmoud, MA, Lee, DW, Zhou, D, Keller, AA: Mobility of capped silver nanoparticles under environmentally relevant conditions. Environ. Sci. Technol. 46(13), 6985-6991 (2012)

35. Piccapietra, F, Sigg, L, Behra, R: Colloidal stability of carbonate-coated silver nanoparticles in synthetic and natural freshwater. Environ. Sci. Technol. 46(2), 818-825 (2012). doi:10.1021/es202843h

36. Li, X, Lenhart, Jj: Aggregation and dissolution of silver nanoparticles in natural surface water. Environ. Sci. Technol. 46(10), 5378-5386 (2012)

37. Kent, RD, Vikesland, PJ: Controlled evaluation of silver nanoparticle dissolution using atomic force microscopy. Environ. Sci. Technol. 46(13), 6977-6984 (2012)

\subsection{6/2228-5326-3-54}

Cite this article as: Zhong: Physicochemical properties of protein-modified silver nanoparticles in seawater. International Nano Letters 2013, 3:54

\section{Submit your manuscript to a SpringerOpen ${ }^{\circ}$ journal and benefit from:}

- Convenient online submission

$\checkmark$ Rigorous peer review

- Immediate publication on acceptance

- Open access: articles freely available online

- High visibility within the field

- Retaining the copyright to your article

Submit your next manuscript at $\downarrow$ springeropen.com 